\title{
PATHOLOGICAL CLASSIFICATION AND ETIOLOGICAL PREVALENCE OF ENDOMETRITIS IN EWES SUFFERING FROM INFERTILITY PROBLEMS
}

\author{
U.H. ABO-SHAMA*; S.KH. ABD ELGHAFFAR ${ }^{* *}$; M.KH. ABD-EL-RAHMAN ${ }^{* *}$; A.E. ZAIN ${ }^{* * *}$ and \\ F.A. ABU ZAKAIB ${ }^{* * *}$. \\ * Department of Microbiology and Immunology, Faculty of Vet. Med., Sohag University. \\ ** Department of Pathology, Fac. Vet. Med., Assiut University. \\ *** Faculty of Vet. Med., Sohag University. \\ Email: usama.shama@yahoo.com
}

\section{ABSTRACT}

Received at: 16/12/2013

Ewes in Sohag Governorate, Egypt are suffering from many infertility problems such as abortion, repeat breeder, anoestrus, cystic ovary and endometritis. The purpose of this study is to investigate reproductive problems that may occur in sheep at Sohag governorate, Egypt using pathological, bacteriological and serological

Accepted: 23/1/2014 examinations One hundred ewes slaughtered in abattoirs at Sohag Governorate, Egypt were included in this study. These animals were suffered from many infertility problems according to the owners complain, their age ranged from 3 to 6 years. Blood samples were collected from each animal before slaughtering for serological examination. After slaughtering, the genital tracts were collected and examined grossly. Bacteriological swabs were taken from the lumen of the uterus and processed for bacteriological examination. Uterine samples were processed for histopathological examination. The uterine lesions were classified into 30 cases lymphoplasmocytic endometritis, 5 cases lymphoplasmocytic metritis, 18 cases acute catarrhal endometritis, 29 cases chronic catarrhal endometritis, one case fibrinonecrotic endometritis, 4 cases suppurative endometritis and 8 cases adenomyosis. Serological examination of blood samples and bacteriological examination of swabs of 60 cases indicated that, there are various species of bacteria were present and confirmed serologically positive for Brucella, Salmonella or toxoplasma. This examination revealed that Staph aureus which isolated from 2 cases (3.33\%), Staph aureus with Streptococcus species isolated from 1 (1.66\%) case, Streptococcus species was isolated from 3(5\%) cases, Streptococcus isolated from $1(1.66 \%)$ case associated with serologically positive Brucella, Proteus species was isolated from $1(1.66 \%)$ cases, E-coli were isolated from $1(1.66 \%)$ case associated with Salmonella species, Salmonella species was isolated and detected by widal test in 9 cases $(15 \%)$, Salmonella species detected in association with toxoplasma antibodies in $1(1.66 \%)$, toxoplasma antibodies were serologically detected also in another 6 cases $(10 \%)$ and Brucella antibodies were serologically detected by rose Bengal test in association with toxoplasma antibodies in one case $(1.66 \%)$.

Keyword: Ewes, endometritis, metritis, toxoplasma, Brucella

\section{INTRODUCTION}

Sohag Governorate considered the second province in sheep production after Kina governorate. It has 416472 head of sheep and 423141 head of goat (Agriculture ministry and land reclamation, 2009). Ewe in Sohag Governorate are suffering from many infertility problems such as abortion, repeat breeder, anoestrus, cystic ovary and endometritis. Sheep have high survival rates under drought conditions compared to cattle. Moreover, They provide their owners with a vast range of products and services such as meat, milk, skin, hair, horns, bones, manure and urine for cash, security, gifts, religious rituals, and medicine, etc. (Alemu and Merkel, 2008). Due to their short reproductive cycles (short lambing/kidding interval) and high incidence of multiple births. This allows farmers/producers a quick interval of selling part of their flock and generating cash income. (Alemu and Merkel, 2008).

Female reproductive pathology seems to be underestimated in ovine species and, in most cases; severe gross lesions are missed due to the lack of specific clinical signs. Moreover, pathologists may support flocks dealing with subtle reduced fertility owing to subclinical endometritis by means of endometrial biopsies and histological examination. Although this technique could be a valuable diagnostic and research tool for assessing postpartum uterine function or health, many defects may escape notice by owners, resulting in poor reproductive 
performances of the flock. Approperiate careful clinical examination and examination of slaughterhouse uterine samples should be made for a sound breeding program.

The purpose of this study is to investigate reproductive problems that may occur in sheep at Sohag Governorate, using pathological, bacteriological and serological examinations.

\section{MATERIALS and METHODS}

A total 100 genital tracts collected from ewes slaughtered at abattoirs in Sohag governorate during 2011. Female sheep aged 1-6 years was used for this study. These animals were suffered from infertility problems according to the owners complain. Specimens from uterus of examined animals were taken after the gross pathological examination. The samples were fixed in neutral buffer formalin. Bacteriological swabs were taken from uterus as well as blood sample collected for serological examination

\section{Preparation of tissue specimens for Pathological examination}

The tissue specimens were fixed in neutral buffer formalin, dehydrated in ascending grades of ethyl alcohol, cleared and embedded in paraffin blocks. Sections of 5-7 $\mu \mathrm{m}$ were made and stained with $\mathrm{H}$ and E stain (Bancroft and Stevens 1982) and examined by light microscope.

\section{Preparation of samples for Bacteriological examination \\ A- Direct microscopic examination:}

Direct smears were made with a platinum loop on clean sterile slides. Screening study of morphology and staining character of the prevalent microorganisms, were carried out using stained films.

B- Isolation and identification of micro-organisms: For detection of $S$. aureus \& Streptococcus: Culture of swab samples using Nutrient broth, Nutrient agar, Mannitol salt agar, Baird Paker agar, Blood agar plates, The plates were incubated for 24 hours at $37^{\circ} \mathrm{C}$. Gram stain, catalase, coagulase and VogesProskaver (VP) tests were conducted on suspected colonies.

For detection of Proteus, E. coli \& Salmonella: Culture of swab samples using Nutrient agar, Semisolid soft agar, Blood agar plates, S.S agar, Eosin methylene blue agar \& MacConkey's agar were used for isolation of coliforms and other members of the family Enterobacteriaceae. The plates were incubated at $37^{\circ} \mathrm{C}$ for $24 \mathrm{~h}$. Five randomly selected colonies from MacConkey's agar and 10 per cent sheep blood agar plates were picked up and subculture on eosin methylene blue (EMB) agar plates to observe the characteristic metallic sheen of E. coli. Proteus Sp show swarming phenomena on nutrient agar and show motility on semisolid soft agar. The culture was characterized by biochemical tests i.e., API 20E test kit, Indole Test, Methyl Red, Voges-Proskauer Test, Citrate Utilization Test, Carbohydrate Fermentation Test, Nitrate reduction test and Catalase Test for identification of isolates (Holt et al., 1994)

\section{C- Serological examination of serum samples}

Rose Bengal test routinely done to all collected serum samples for detection of brucella antibodies Serum plate agglutination test (TAYTEC TOXO LATEX KIT, Canada) for detection of toxoplasma antibodies, Slide rapid agglutination test (ACCUCARETM WIDAL SLIDE TEST, India) for detection of salmonella antibodies.

\section{RESULTS}

\section{Pathological examination}

In this study, 100 female genital tract from ewes slaughtered at abattoirs in sohag Governorate were examined grossly and histopathologically. The pathological examination revealed many pathological lesions which could be summarized in table (1).

According to the histopathological examination, the uterine lesions were classified into: 1lymphoplasmocytic endometritis (Fig. 1) recorded in 30 cases, 2- lymphoplasmocytic metritis (Fig. 2) in 5 cases, 3- acute catarrhal endometritis (Fig. 3) in 18 cases, 4- chronic catarrhal endometritis (Fig. 4) in 29 cases, 5- fibrinonecrotic endometritis (Fig. 5) in 1 case, 6- suppurative endometritis (Fig. 6) in 4 cases, and 7-adenomyosis (Fig.7) in 8 cases.

\section{Bacteriological examination}

Lesions associated with microorganisms isolated from 60 cases were summarized in table (1). Serological examination of blood samples and bacteriological examination of swabs of 60 cases indicating that, there are various species of bacteria were present at the uterus as well as serologically positive cases for either Brucella, Salmonella or toxoplasma. This examination revealed that: Staph aureus which isolated from 2 cases (3.33\%), Staph aureus with Streptococcus species isolated from 1 $(1.66 \%)$ case, Streptococcus species was isolated from 3(5\%) cases, Streptococcus isolated from $1(1.66 \%)$ case associated with serologically positive Brucella, On the other hand, Proteus species was isolated from $1(1.66 \%)$ cases, E-coli were isolated from $1(1.66 \%)$ case associated with Salmonella species, Salmonella species was isolated and detected by widal test in 9 cases $(15 \%)$, Salmonella species detected in association with toxoplasma antibodies in $1(1.66 \%)$.

Serologically examination of serum revealed Toxoplasma antibodies were detected also in another 6 cases $(10 \%) \&$ Brucella antibodies were detected by Rose Bengal test in association with Toxoplasma antibodies at 1 case $(1.66 \%)$. 
$\underline{\text { Assiut Vet. Med. J. Vol. } 60 \text { No. } 140 \text { January } 2014}$

Table 1: Lesions associated with microorganisms isolated from 60 cases.

\begin{tabular}{|c|c|c|c|}
\hline $\begin{array}{c}\text { Isolated and serologically } \\
\text { +ve Microorganisms }\end{array}$ & No & $\%$ & Lesions \\
\hline Staph aureus* & 2 & $33.3 \%$ & Fibrinonecrotic endometritis. \\
\hline $\begin{array}{l}\text { Staph aureus } \\
\text { streptococcus*. }\end{array}$ & 1 & $1.66 \%$ & Acute catarrhal endometritis. \\
\hline Streptococcus*. & 3 & $5 \%$ & $\begin{array}{l}\text {-Acute suppurative endometritis. } \\
\text {-Chronic catarrhal endometritis. } \\
\text {-Cystic endometrial hyperplasia. }\end{array}$ \\
\hline $\begin{array}{l}\text { Streptococcus } \\
\text { Brucella. }\end{array}$ & 1 & $1.66 \%$ & Lymphoplasmocytic endometritis. \\
\hline Proteus spp*. & 1 & $1.66 \%$ & Lymphoplasmocytic endometritis. \\
\hline E-coli *; Salmonella*\&**. & 1 & $1.66 \%$ & Chronic catarrhal endometritis \\
\hline Salmonella*;**. & 9 & $15 \%$ & $\begin{array}{c}\text {-Lymphoplasmocytic endometritis. } \\
\text {-Acute catarrhal cervicitis }\end{array}$ \\
\hline $\begin{array}{l}\text { Salmonella*,**; } \\
\text { Toxoplasma**. }\end{array}$ & 1 & $1.66 \%$ & $\begin{array}{c}\text {-Chronic catarrhal endometritis. } \\
\text {-Adenomyosis }\end{array}$ \\
\hline Toxoplasma**. & 6 & $10 \%$ & $\begin{array}{l}\text {-Lymphoplasmocytic endometritis. } \\
\text {-Chronic catarrhal endometritis. } \\
\text {-Adenomyosis. } \\
\text {-Acute catarrhal cervicitis. }\end{array}$ \\
\hline $\begin{array}{l}\text { Toxoplasma } * * ; \\
\text { Brucella }^{* *}\end{array}$ & 1 & $1.66 \%$ & Lymphoplasmocytic endometritis \\
\hline Total & 26 & $43.33 \%$ & \\
\hline
\end{tabular}

\section{*: Bacteriological positive cases.}

$* *$ : Serological positive cases.

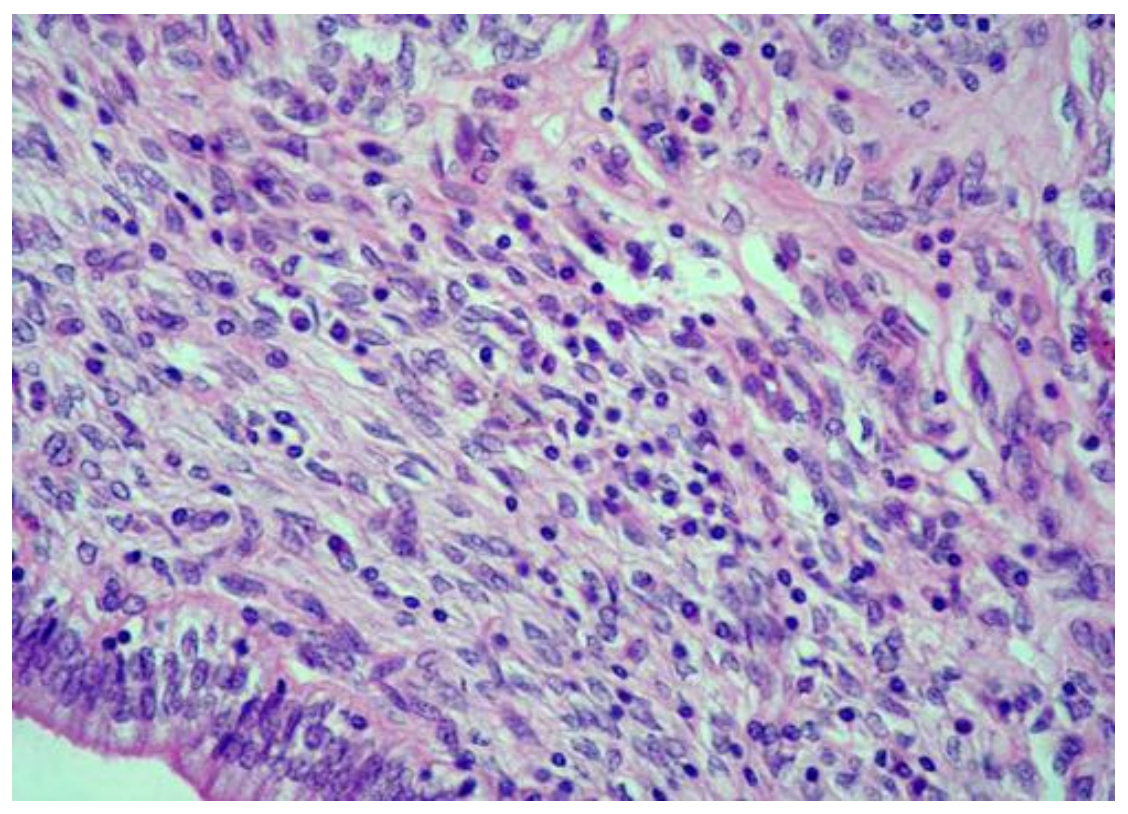

(Fig.1): Uterus of ewe showing lymphoplasmocytic endometritis( arrow). Lymphocytes and plasma cells were seen infiltrating subepithelial layer. H\&E. X 40. 


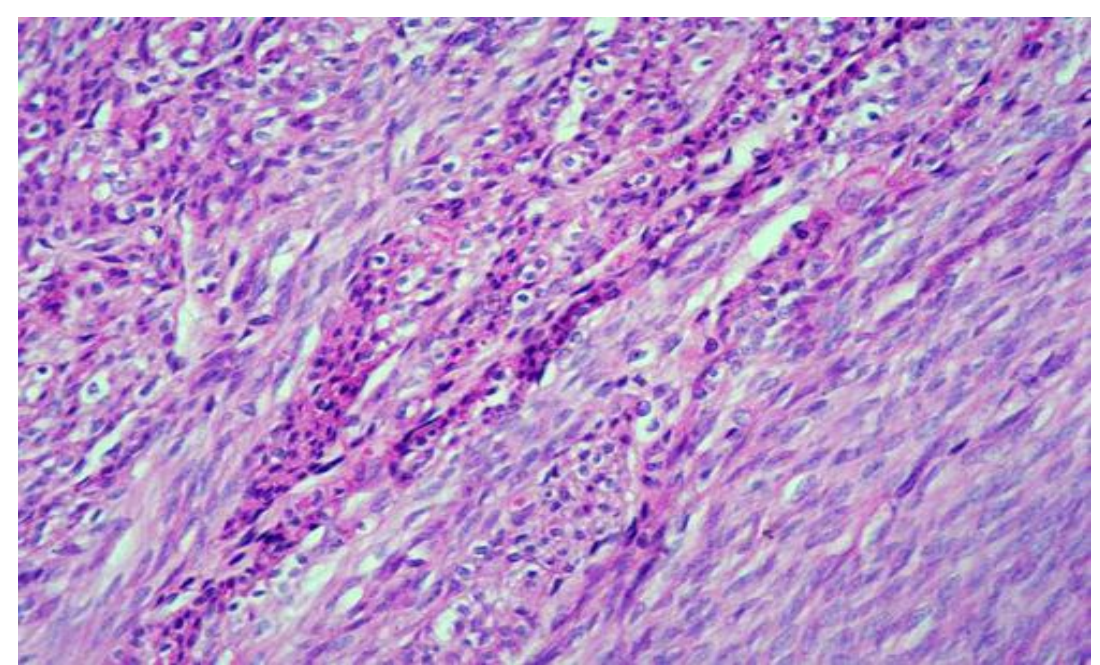

(Fig. 2): Uterus of ewe showing lymphoplasmocytic metritis. Sever infiltration by plasma cells and lymphocytes between and in all layers of myometrium (arrow). H\&E. X 40.

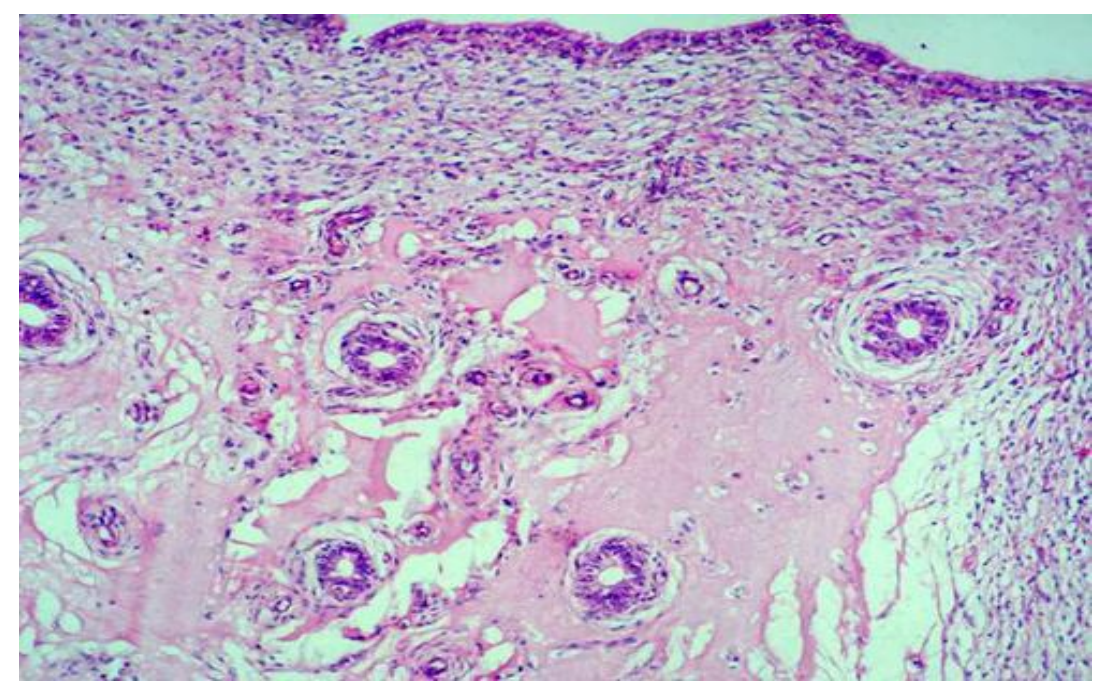

(Fig. 3): Uterus of ewe showing acute catarrhal endometritis. Catarrhal exudates with inflammatory cells were noticed at sub epithelial layer (arrow). H \& E stain. X 10.

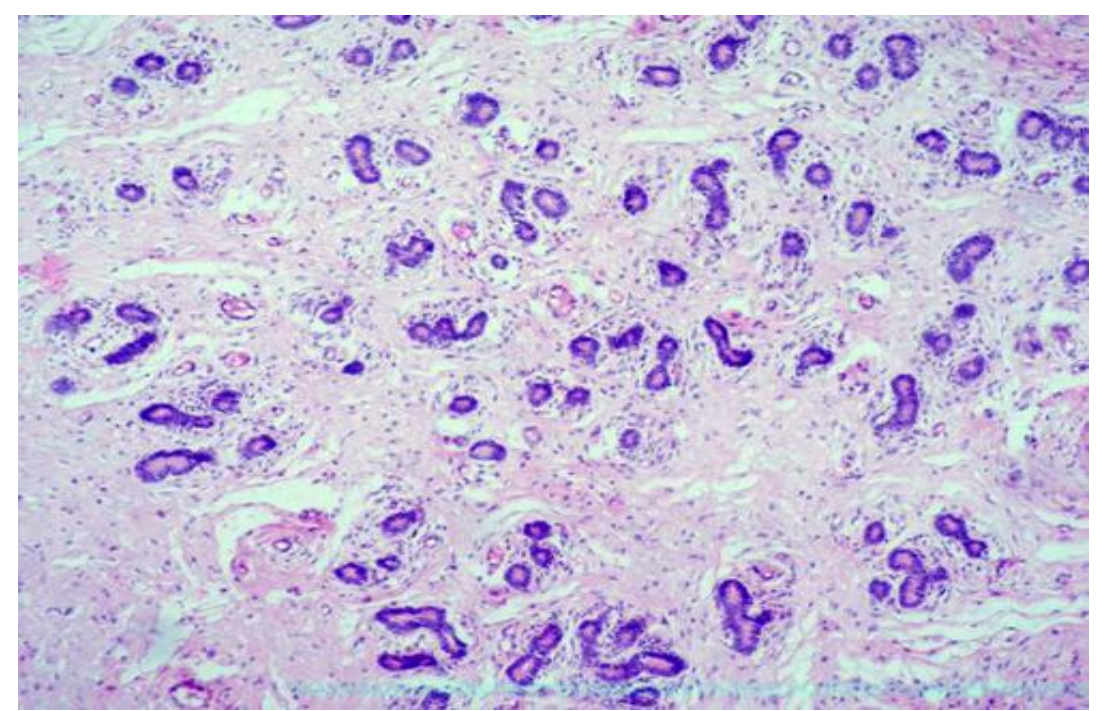

(Fig. 4): Uterus of ewe showing chronic catarrhal endometritis. Endometrial glands were atrophied (arrow) and separated from each others with connective tissue fibers. H \& E stain. X 10. 


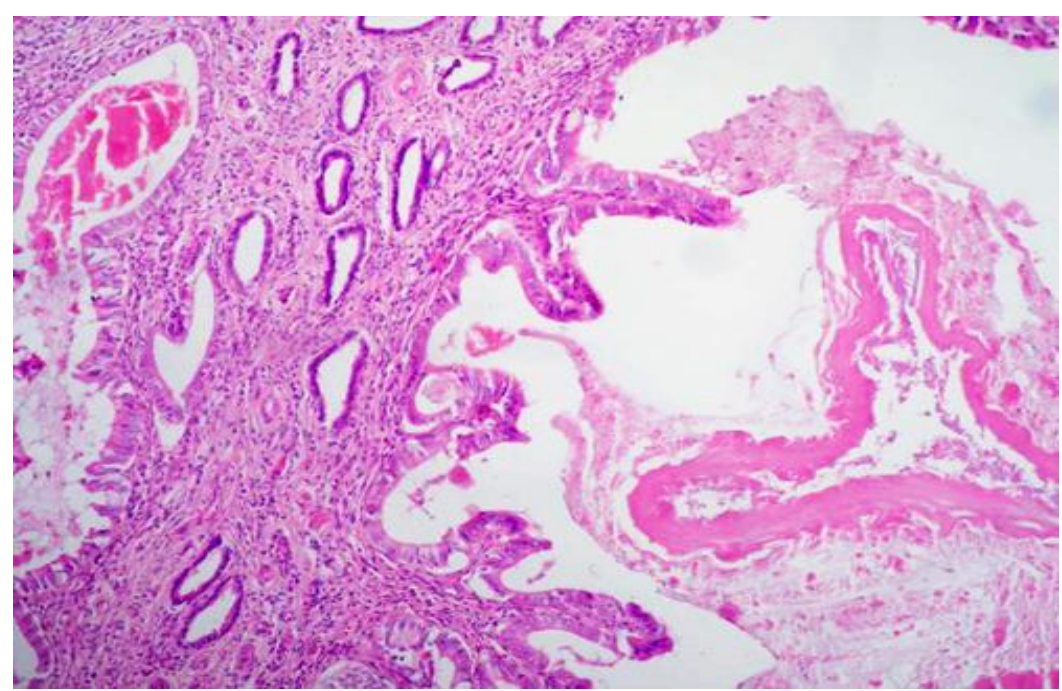

(Fig. 5): Uterus of ewe showing fibrinonecrotic endometritis. Clots of fibrin at lumen mixed with inflammatory cells (neutrophils), hyperemia of blood vessels (V) and lymphocytic cell reaction at sub epithelial layer. H \& E tain. X 10.

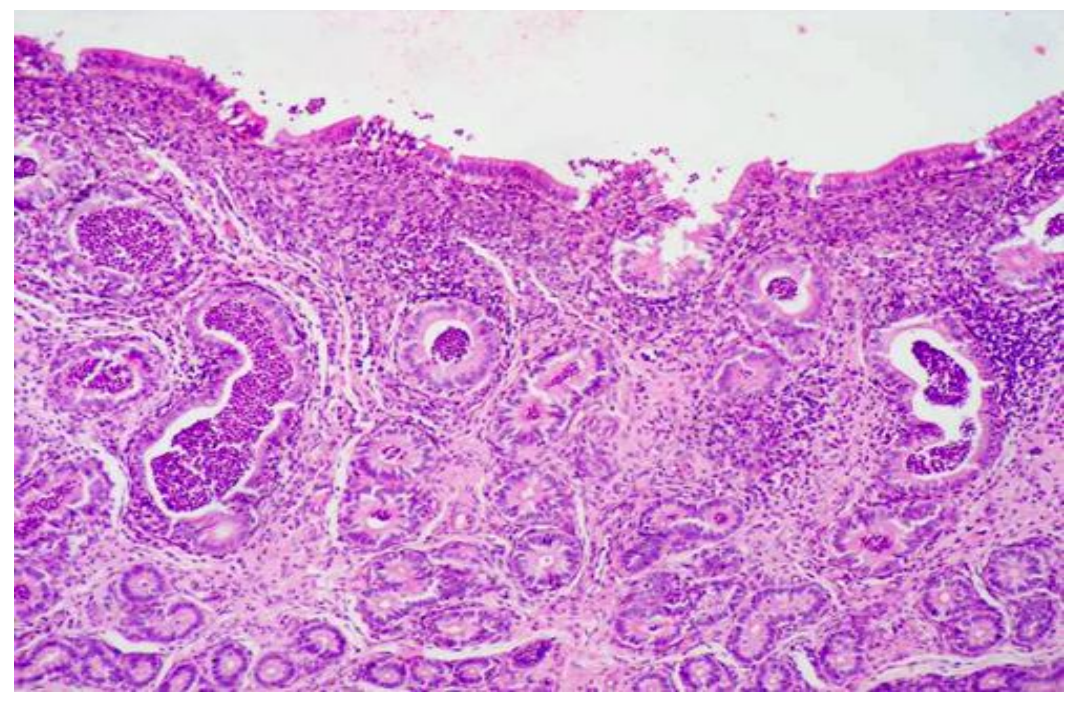

(Fig. 6): Uterus of ewe showing suppurative endometritis. Sloughed and necrotic epithelium of endometrium (arrow) with heavy infiltration of neutrophil cells (Head arrow). H \& E stain. X 10.

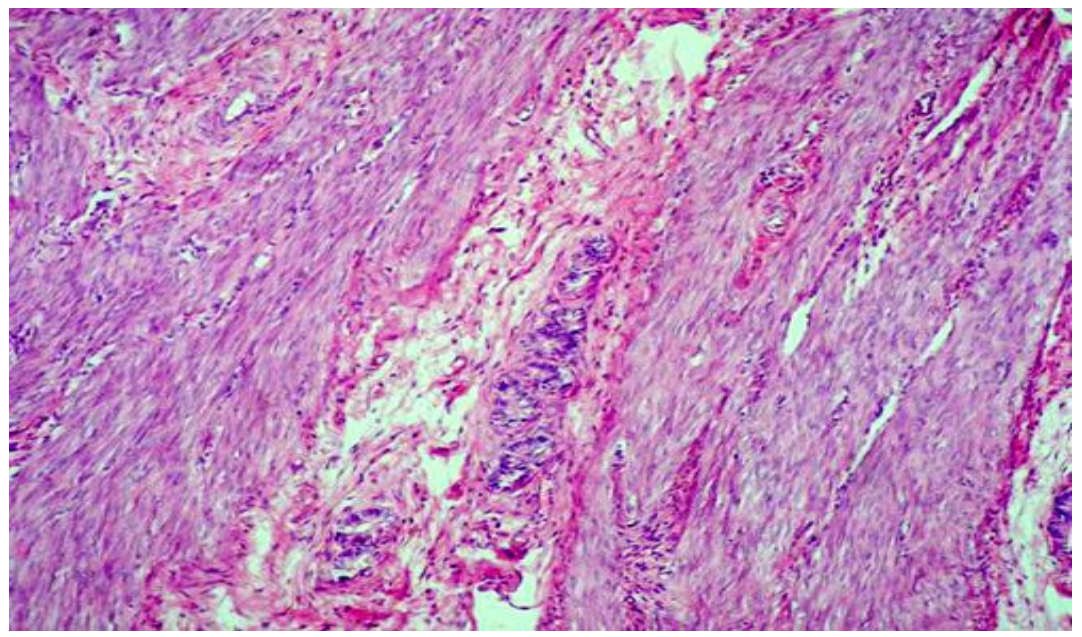

(Fig. 7): Uterus of ewe showing adenomyosis. Nests of endometrial glands with surrounding stroma had grown from endometrium in between muscles layers. H \& E stain. X 10. 


\section{DISCUSSION}

In this study we deal with the gross and microscopic lesions encountered in 100 genital tract collected at slaughterhouse specimens from Sohag abattoirs.

Since the healthy endometrial condition is necessary for the fertility of the animal so, any alteration in the normal histological structure may impair fertility or cause permanent sterility. This consideration was reported by El-Naggar and El-Sherry (1974).

From our results 95 cases out of 100 slaughtered ewes showed pathological changes in the uterus. These pathological changes included lymphoplasmocytic endometritis in 30 case, lymphoplasmocytic metritis in 5 cases, acute catarrhal endometritis in 18 cases, chronic catarrhal endometritis in 29 case, fibrinonecrotic endometritis in 1 case and suppurative endometritis in 4 cases, while adenomyosis was observed in 8 cases. Sokkar et al. (1980) reported that, out of 100 uteri of ewes collected from a slaughterhouse, 44 had endometritis. These cases were classified as acute endometritis (18\%), acute lymphocytic endometritis (59\%), chronic nonsuppurative endometritis (16\%) and suppurative endometritis $(6.8 \%)$.

Acute lymphoplasmocytic endometritis was recorded in 30 cases. this result agree with (Barlund et al., 2008; Gilbert et al., 2005 and Kasimanickam et al., 2004), they stated that subclinical endometritis prevalence ranges from $11 \%$ to $53 \%$.

In these cases we isolate Proteus species from 1 case, Salmonella from 2 cases. Streptococcus was recorded in 1 case in association with Brucella antibodies in the serum. Toxoplasma antibodies was detected in serum of 1 case, also it was detected at another case in association with antibodies of Brucella spp. These types of metritis and/or endometritis was recorded at the postpartum period (Arthur and Pearsonl 1982). In postpartum period, the uterus seems to be able to prevent bacteria from achieving infection unless suppression to uterine defense mechanism occurs (Seals et al., 2002). The microfloras have no pathological effect without supporting from other predisposing or stress factors (Azawi et al., 2008). Previous studied recorded that $56.5 \%$ of genital tracts contains microflora including, Arcanobacterium pyogens, Escherichia coli and Streptococci Spp commonly isolated from uteri of ewes (Aziz et al., 2000`and Al-Hamedawi et al., 2002). Also members of the genus Staphylococcus sp. have been reported, in ewes (Sawyer, 1977).

Acute catarrhal endometritis which described in our results, in 18 cases, characterized by roughness in mucosal surface with petechiae'and some accumulation of thin or viscid fluid in the uterine lumen. Microscopically, there were hydropic degeneration at epithelial lining, with sever infiltration of endometrium by plasma cells and some lymphocytes. At 4 cases of them the acute inflammation extended to include all layers, in which the myometrium infiltrated by plasma cells and lymphocytes. The preimetrium showing congestion, edema and lymphocytic cell infiltration. Similar findings of endometritis were described by (Runnells et al., 1965; 'Bollo et al., 1990 and Jubb et al., 1993).

In these cases we isolate staphylococcus aureus associated with Streptococcus species were isolated from 1 case and the antibodies of toxoplasma detected in 1 case Antibodies of Salmonella species were detected in another case of acute catarrhal endometritis.

Chronic catarrhal endometritis which described in our results in 29 cases, characterized by desquamation in the epithelium lining the endometrium, hyperplasia or metaplasia in some areas, other areas showed epithelial necrosis and desquamation. Lymphocytic cell infiltration of the epithelial layer, or subepithelial layer or surrounding the endometrial glands were also recoded. At 2 cases of chronic catarrhal endometritis, the endometrium was markedly expanded by many irregular cystic and hyperplastic glands, some of these glands contained scattered neutrophils, sloughed epithelial cells, cellular debris, and fibrin. The glands were lined by either normal or hyperplastic epithelium. The endometrial vessels showed perivascular fibroblastic proliferation and infiltration of lymphocytes and plasma cells. In 4 cases of them, the chronic catarrhal inflammation extended to include all layers, in which the infiltrated inflammatory cells were seen between the degenerated myometrium layer and at perimetrium. Nearly similar picture of endometrits were previously described by El-Naggar and ElSherry (1974) and Jubb et al. (1993). Streptococcus species was isolated from 1 case, E-coli associated with Salmonella species was isolated from 1 case, antibodies of Toxoplasma were detected in serum of 1 case, and with antibodies of Salmonella from another q case.

Our results indicated that fibrinonecrotic endometritis was recorded in one case in which the utrine lumen contained a large amount of clotted exudates admixed with blood. The fibrinous exudates appeared as a red network of fibrin clots at the surface entangling acute inflammatory cells, mostly lymphocytes and neutrophiles. The epithelial layer of endometrium was necrosed and sloughed. At sub epithelial layer lymphocytic cells aggregated and blood vessels were congested. This observation was recorded also by Runnells et al. (1965). Staphylococcus aureus was isolated from this case. 
Our results revealed that, there were 4 cases out of 100 female genital tracts showed suppurative endometritis which characterized by degenerative changes in some areas of endometrial epithelium, other areas showed epithelial hyperplasia and other showed epithelia degeneration and necrosis. At upper third of endometrium there are sever infiltration by neutrophils. Endometrial glands showing cystic hyperplasia with preiglandular fibrosis, the lumen of these glands filled with suppurative exudates infiltrated with neutrophils. Similar results were previously described by Runnells et al. (1965), Bollo et al. (1990) and Dawood (2010).

In these 4 cases, the endometrium was markedly expanded by many irregular cystic and hyperplastic glands, some of these glands contained widely scattered neutrophils, sloughed epithelial cells, cellular debris, and fibrin. The glands were lined by either normal, hyperplastic epithelium. Some endometrial epithelial cells were swollen with clear to foamy cytoplasm. The blood vessels showed medial hyperplasia. Similar lesions were previously described by (Feldman and Nelson, 1996). We isolate Streptococcus species from 1 case of suppurative endometritis.

Bacterial organisms are considered to be the predominant cause of endometritis. Bacteriological examination of our investigated ewes revealed many isolates of bacterial associated with the different types of endometrial lesions as Staphylococcus aureus, streptococcus, E-coli, Salmonella, toxoplasma and Brucella species. Endomeritis due to bacterial infection was described by several authors as Sokkar et al. (1980), who reported that, Corynebacterium pyogenes, Escherichia coli and Streptococci are the organisms commonly isolated from the uteri of ewes and E. coli and streptococci appear to be the organisms commonly associated with endometritis. Also Al-Hamedawi et al. (2002) and Aziz et al. (2000) reported that $56.5 \%$ of genital tracts contains microflora including, Arcanobacterium pyogens, Escherichia coli and Streptococci Spp which are commonly isolated from uteri of ewes. Also Sawyer (1977) isolate genus Staphylococcus sp from cases of endometritis in ewes.

\section{REFERENCES}

Agriculture ministry and land reclamation. (2009): www. Agriculture ministry and land reclamation.org.

Alemu Yami and Merkel, R.C. (2008): Review of Sheep and Goat Production Handbook for Ethiopia. chapter 1.1-5.

Al-Hamedawi, T.M.; Khammas, D.J. and Al-Ubaidi, A.S. (2002): Effect of estrous synchronization on vaginal flora and subsequent fertility in ewe. Iraqi J. Vet. Sci., 16:1:73-79.
Arthur, G.H. and Pearson, H. (1982): In: Veterinary Reproduction and obstetrics, 2nd edition, pp. 317-324, Bailliere Tindall, East Sussex Of their first pregnancy. Vet. J. 163, 329-330.

Azawi, O.I.; Omran, S.N. and Hadad, J.J. (2008): Treatment of toxic puerperal metritis in Iraqi buffalo cows Veterinarski Arhiv, 78 (6), 487499.

Aziz, D.M.; Al-Sultan, M.A.H. and Al-Jawally, E.A.K. (2000): Uterine micro flora in Awassi ewes. Iraqi J. Vet. Sci., 13:1:201-205.

Bancroft, I.D. and Stevens, A. (1982): Theory and practice of histologic techniques. Second edition. Longman Group Limited.

Barlund, C.S.; Carruthers, T.D.; Waldner, C.L. and Palmer, C.W. (2008): A comparison of diagnostic techniques for postpartum endometritis in dairy cattle. Theriogenology 69, 714-723.

Bollo, E.; Biolatti, B.; Pau, S. and Galloni, M. (1990): Scanning electron microscopy of pathologic changes in the epithelial surfaces of the uterus and uterine tubes. Am J. Vet. Res., Vol. 51, No. 1, January. 137-142.

Dawood, K.E. (2010): Pathological abnormalities of the reproductive tracts of ewes in Basra, Iraq, Vet. Rec. 166 (7), pp. 205-207.

El-Naggar, M.A. and El-Sherry, M.I. (1974): Incidence and pathological changes in endometrial biopsy of the repeat breaders buffaloaes in Assiut province Egypt. Assiut Vet. Med.J.,Vol.1. No1 and 2,269-279.

Feldman, EC. and Nelson, RW. (1996): Cystic endometrial hyperplasia/ pyometra complex. In: Canine and feline endocrinology and reproduction, ed. Feldman EC, Nelson RW, 2nd ed., pp. 605- 618. WB Saunders, Philadelphia, PA.

Gilbert, R.O.; Shin, S.T.; Guard, C.L.; Erb, H.N. and Frajblat, $M$. (2005): Prevalence of endometritis and its effects on reproductive performance of dairy cows. Theriogenology 64, 1879-1888.

Holt, JG.; Krieg, NR.; Sneath, PH.; Stanley, JT. and Williams, ST. (1994): Bergey's Manual of Determinative Bacteriology. Williams and Wilkins Baltimore., pp. 529-550.

Jubb, K.V.F.; Kennedy, P.C. and Palmer, N. (1993): Pathology of Domestic animals. Fourth Edition Volume 3. Academic Press. New Yourk.

Kasimanickam, R.; Duffield, T.F.; Foster, R.A.; Gartley, C.J.; Leslie, K.E.; Walton, J.S. and Johnson, W.H. (2004): Endometrial cytology and ultrasonography for the detection of subclinical endometritis in postpartum dairy cows. Theriogenology 62, 9-2.

Runnells, R.A.; Monlux, W.S. and Monlux, A.W. (1965): Principles of veterinary pathology. $7^{\text {th }}$ Edition. The LOWA STATE University press, AMES.LOWA.U.S.A. 
Sawyer, G.J. (1977): Observation on the bacterial population of the on cervix of the ewe before and after embryo death. Australian Veterinary Journal, v. 53, p. 542-544.

Seals, R.C.; Wulster-Radcliffe, M.C. and Lewis, G.S. (2002): Modulation of the uterine response to infectious bacteria in postpartum ewes. Am. J.
Reprod. Immunol., 47:57-63.sheep: immune control versus fetal pathology. J.R. Soc. Med. 94, 273-277.

Sokkar, S.M. and Kubba, M.A. (1980): Pathological studies on the fallopian tubes of ewes, Zentralblatt fur Veterinarmedizin Vol. 27A No. 2 pp. 118-122.

\title{
التصنيف الباثولوجي ومدي انتثار المسبب لمرض التهاب بطانة الرحم في إناث الأغنام التي تعانى من مشاكل العقم
}

\author{
أسامة حسن أبوثامه عبد الصادق ، سارى خليل عبدالغفار ، محد خيرى عبدالرحمن ، علاء الدين زين العابدين محمود \\ فاطمة أبو زكايب أحمد غلى فلى علئ \\ Email: usama.shama@yahoo.com
}

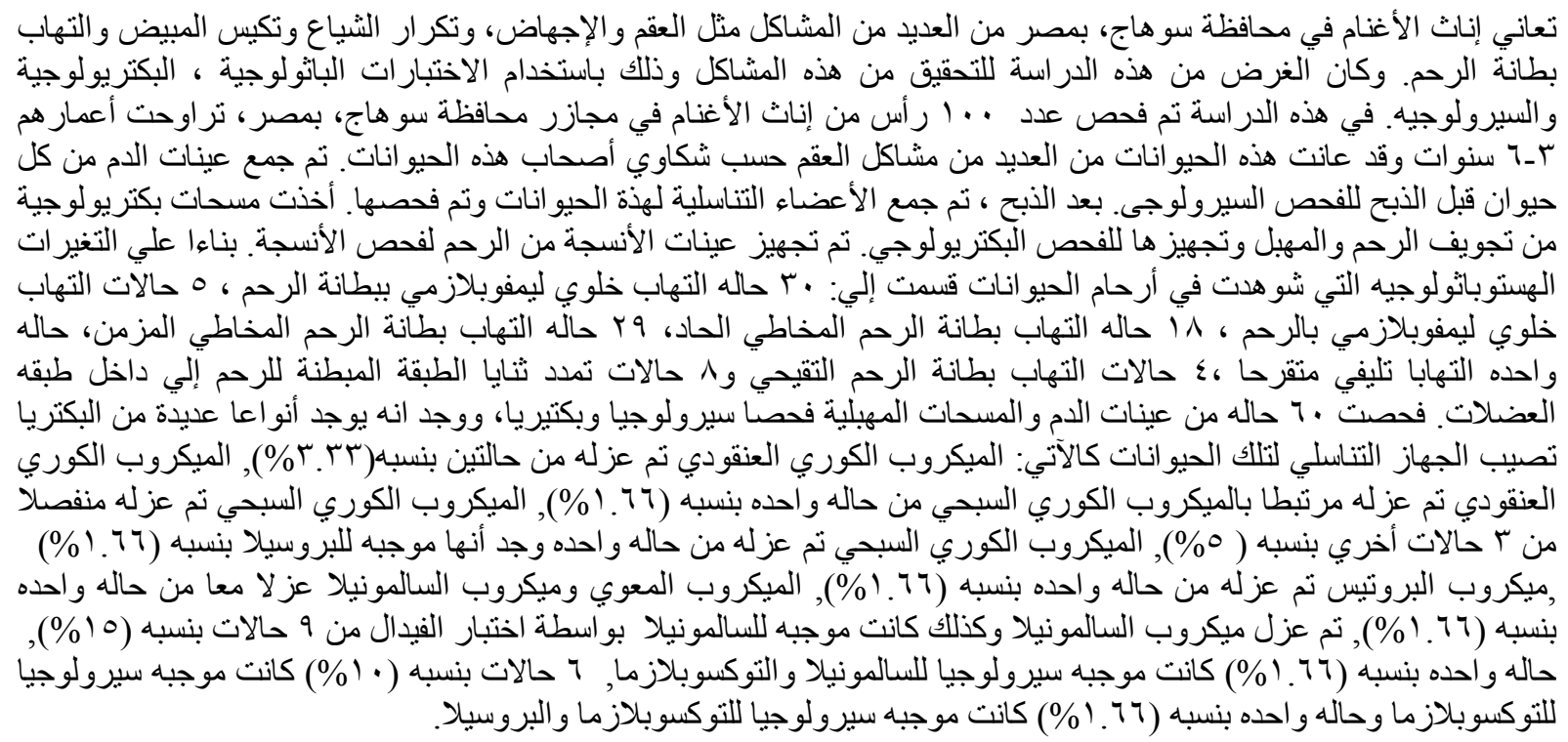

